\title{
PELAKSANAANPEMBELAJARAN BERBASISPENDEKATANSAINTIFIK PADA MATA PELAJARAN SENI BUDAYA MATERI SENI RUPADI SMPN BUKITTINGGI
}

\author{
Wisdiarman $^{1 *}$, Eliya Pebriyeni $^{2 *}$, Yofita Sandra $^{3 *}$, Nessya Fitryona $^{4^{*}}$ \\ Program Studi Pendidikan Seni Rupa Jurusan Seni Rupa Fakultas Bahasa dan Seni \\ Universitas Negeri Padang \\ Jl. Prof. Dr. Hamta, Air Tawar Padang, Kel. Air Tawar Barat, Kec. Padang Utara, Kota Padang, Kode Pos 25171 \\ Sumatera Barat. Indonesia \\ Email:wisdiarman@gmail.com
}

\begin{abstract}
Abstrak
Penelitian ini bertujuan untuk memperoleh gambaran tentang pelaksanaan pembelajaran seni budaya materi seni rupa berbasis pendekatan saintifik di SMP Bukittinggi. Metode yang digunakan dalam penelitian ini adalah metode deskriptif kualitatif. Subjekdalampenelitianiniadalahguru seni budaya di SMP Kota Bukittinggi. Teknik pengumpulan dat amenggunakan teknik observasi, wawancara, dan dokumentasi. Instrumen penelitian yang digunakan yaitu pedoman observasi dan pedoman wawancara.Teknik analisis data yang digunakan adalah teknik analisis yang meliputi reduksi data, penyajian data, sertapenarikan kesimpulandan verifikasi. Pengujian keabsahan data dilakukan melaluiuji kredibilitas dengan triangulasi teknik dan sumber.Temuan penelitian menunjukkan bahwa: Pertama; guru seni budaya SMPN Bukittinggi sudah membuat Rencana Pelaksanaan Pembelajaran (RPP) berdasarkan pendekatan saintifik. Tetapi dalam perumusan masing-masing langkah belum sesuai dengan ketentuannya. Kedua; guru seni budaya SMPN Bukittinggi belum lagi melaksanakan strategi/model pembelajaran berdasarkan pendekatan saintifik sesuai dengan yang diharapkan. Hal ini karena ketidak pahaman guru terhadap penggunaan strategi/model dan langkah-langkahpembelajaran berdasarkan pendekatan saintifik.
\end{abstract}

Kata Kunci: pelaksanaan pembelajaran, pembelajaran berbasis pendekatan saintifik.

\begin{abstract}
This study aims to obtain an overview of the implementation of art and culture learning art material based on the scientific approach in Bukittinggi Middle School. The method used in this study is a qualitative descriptive method. The subject of this research is the teacher of cultural arts in the Bukittinggi City Middle School. The technique of collecting data uses observation, interview, and documentation techniques. The research instruments used were observation guidelines and interview guidelines. Data analysis techniques used were analytical techniques which included data reduction, data presentation, as well as drawing conclusions and verification. Testing the validity of the data is done through testing credibility with triangulation of techniques and sources. The findings of the study show that: First; Bukittinggi Public High School art teacher has made a Learning Implementation Plan $(R P P)$ based on a scientific approach. But in the formulation of each step not in accordance with the provisions. Second; Bukittinggi Middle School teachers of cultural arts have not yet implemented strategies / learning models based on the scientific approach as expected. This is due to the teacher's lack of understanding of the use of strategies / models and learning steps based on the scientific approach
\end{abstract}

Keywords: implementation of learning, learning based on scientific approaches.

\section{PENDAHULUAN}

Agar bangsa Indonesia mampu bersaing dan eksis dalam era globalisasi, diperlukan sumber daya manusia yang berkualitas dalam arti memiliki kemampuan berkreasi, mampu memecahkan masalahmasalah aktual dalam kehidupan dan mampu mengambil keputusan yang menjangkau kedepan. Untuk itu diperlukan karakteristik manusia masa depan. Menurut Budiningsih (2005) karakteristik manusia masa depan yang dikehendaki adalah manusia yang berkualitas, yakni manusia-manusia yang memiliki kepekaan, kemandirian, bertanggungjawab, dan mampu melakukan kolaborasi dalam memecahkan masalah. 


\section{Gorga Jurnal Seni Rupa \\ Volume 07 Nomor 02 \\ p-ISSN: 2301-5942 | e-ISSN: 2580-2380}

Untuk mengembangkan manusia yang berkualitas, perlu diciptakan system pendidikan yang berkualitas dengan penataan yang lebih baik dan disesuaikan dengan perkembangan zaman. Karena zaman selalu berubah, maka pendidikanpun harus disesuaikan dengan perkembangan zaman tersebut. Pendidikan saatini tidak seharusnya fokus mengajarkan kecakapan yang sudah kadaluarsa, seperti menghafal, tetapikemampuan menalar. Namun dari hasil survei menunjukkan bahwa kemampuan menalar siswaIndonesia masih rendah (Kemendiknas, 2012).

Salah satu faktor penyebab rendahnya kemampuan siswa menalar dan memecahkan masalah adalah pendekatan pembelajaran yang diterapkan. Muhibbin Syah (2003). Mengatakan bahwa faktor pendekatan belajar berpengaruh terhadap taraf keberhasilan proses belajar siswa. Pembelajaran yang hanya menekankan hafalan tidak membuat kemampuan siswa menalar berkembang. Oleh karena itu, pendidikan Indonesia harus dirancang untuk siswa berpikir secara kreatif dengan mendorong mereka memutar otak memecahkan suatu persoalan. Seseorang yang mampu berpikir kreatif selalu memiliki jalan solutif dalam proses pemecahan masalah. Ke depannya Bangsa Indonesia membutuhkan anak-anak yang kreatif ditambah unsur produktif, inovatif, serta afektif agar dapat mengatasi permasalahan pada perkembangan zamannya nanti.

Pemikirandi atas menjadi pertimbangan bagi pemerintah dalam melakukan pengembangan kurikulum 2013. Kurikulum 2013 adalah upaya pemerintah untuk meningkatkan mutu pendidikan. Mendikbud (2012) menjelaskan bahwa tujuan Kurikulum 2013 mengarah pada peningkatan kompetensi seimbang antara sikap (attitude), keterampilan (skill), dan pengetahuan (knowledge). Ketiga kompetensi tersebut didukung 4 pilarya itu produktif, kreatif, inovatif, dan afektif. Pengembangan kurikulum baru memberikan banyak perubahan, tidak hanya standar kompetensi lulusan saja yang diubah tetapi standarisi, standar proses, dan standar penilaian ikutdiubah.

Salah satu perubahan yang ada pada kurikulum 2013 adalah pendekatan pembelajaran. Pendekatan pembelajaran yang diamanatkan oleh kutikulum 2013 adalah menerapkan pendekatan saintifik dalam proses pembelajaran. Pembelajaran berbasis pendekatan saintifik diharapkan dapat memberikan pemahaman kepada siswa dalam mengenal dan memahami berbagai materi yang diberikan dengan menggunakan metode ilmiah. Siswa diajarkan menalar dan bagaimana mengambil keputusan, bukan berpikir mekanistis dengan hanya mendengar dan menghafal semata. Siswa juga diberi pemahaman bahwa informasi bisa berasal darimana saja, kapan saja, tidak bergantung pada informasi yang diberikan guru. Oleh karena itu, pembelajaran diarahkan untuk mendorong siswa aktif mencari tahu, mengembangkan kemampuan berlajar, dan membentuk siswa yang kreatif.

Pada awal tahun ajaran baru 2013/2014 Kurikulum 2013 mulai diberlakukan untuk jenjang pendidikan SD/MI,SMP/MTs, dan SMA/SMK. Sebagai konsekuensi dari peraturan pemerintah di atas, maka setiap guru pada satuan pendidikan berkewajiban menyusun RPP dan melaksanakan proses pembelajaran sesuai dengan tuntutan kurikulum 2013 yakni menerapkan pendekatan saintifik.

Pembekalan atau sosialisasi terhadap guru tentang pendekatan saintifik ini telah dilakukan sejak beberapa tahun ini dan seyogyanya para guru sudah memahami dan dapat menerapkan pendektan saintifik ini. Namun pelaksanaan di lapangan, masih ada guru yang belum membuat RPP dan melaksanakan proses pembelajaran berdasarkan pendekatan saintifik. Terutama di SMPN 6 dan SMPN 8 Bukittinggi. Karena sekolah ini baru melaksanakan kurikulum 2013 secara keseluruhan dari kelas VII sampai kelas $\mathrm{X}$ pada tahun ajaran $2017 / 2018$.

Berdasarkan observasi di SMPN 6 dan SMPN 8 Bukittinggi, pada umumnya guru-guru sudah menerapkan pendekatan saintifik, termasuk guru-guru seni budaya. Namun dalam pelaksanaannya belum semua guru yang sudah menerapkan sesuai dengan ketentuan atau prinsip pelaksanaannya. (Wawancara dengan Kepala SMPN 6 dan SMPN 8 Bukittinggi). Hal ini disebabkan karena masih ada guru yang belum memahami cara merancang pendekatan saintifik dalam RPP dan melaksanakan pembelajaran sesuai dengan harapan kurikulum 2013, apalagi guru-guru seni budaya belum pernah mengikuti pelatihahn tentang kurikulum 2013 (Ketua MGMP Seni Budaya SMP kota Bukittinggi).

Berdasarkan hal diataspenulis tertarik untuk meneliti lebih lanjut, apakah guru-guru seni budaya sudah melaksanakan pembelajaran sesuai dengan tuntutan kurikulum 2013 yakni menerapkan pendekatan saintifik dan bagaimanakah pelaksanaannya di SMPN Bukittinggi. Diharapkan hasil penelitian ini dapat dijadikan masukan bagi upaya peningkatan kualitas guru, terutama kualitas pembelajaran. 


\section{Gorga Jurnal Seni Rupa \\ Volume 07 Nomor 02 \\ p-ISSN: 2301-5942 | e-ISSN: 2580-2380}

pembelajaran di kelas. Selanjutnya Mulyasa (2006) mengungkapkan, bahwa rencana pelaksanaan pembelajaran adalah rencana yang menggambarkan prosedur dan manajemen pembelajaran untuk mencapai satu atau lebih kompetensi dasar (KD). Pada hakekatnya rencana pelaksanaan pembelajaran (RPP) merupakan perencanaan jangka pendek untuk memperkirakan tindakan apa yang akan dilakukan dalam pembelajaran. Rencana pelaksanaan pembelajaran (RPP) tersebut disusun untuk setiap KD yang dapat dilaksanakan dalam satu kali pertemuan atau lebih.

Rencana pelaksanaan pembelajaran merupakan penjabaran silabus yang lebih operasional dan rinci. Rencana pelaksanaan pembelajaran merupakan program harian bersifat aplikatif di kelas, disusun oleh guru untuk satu atau beberapa pertemuan untuk mencapai target satu kompetensi dasar (Majid, 2005). Dalam pengembangan rencana pelaksanaan pembelajaran guru harus berpedoman pada silabus yang telah ada. Tugas guru yang paling utama terkait dengan rencana pelaksanaan pembelajaran adalah menjabarkan silabus ke dalam rencana pelaksanaan pembelajaran yang lebih operasional dan rinci, serta siap dijadikan pedoman atau skenario dalam pembelajaran.

Guru yang professional harus mampu mengembangkan rencana pembelajaran yang baik, logis dan sistematis, karena disamping untuk melaksanakan pembelajaran, rencana pelaksaan pembelajaran mengemban "professional accountability", sehingga guru dapat mempertanggung jawabkan apa yang dilakukannya.

Sesuai dengan penjelasan di atas, maka guru dalam melaksanakan pendekatan ilmiah dalam pembelajaran perlu memperhatikan hal-hal penting sebagai berikut:

1. Guru dan Buku Teks bukan satu-satunya sumber belajar

2. Kelas bukan satu-satunya tempat belajar

3. Mengajak siswa mencari tahu, bukan diberi tahu

4. Membuat siswa suka bertanya, bukan guru yang sering bertanya

5. Proses nomer satu, hasil nomer dua

\section{Rencana Pembelajaran (RPP)}

Rencana Pelaksanaan Pembelajaran (RPP) adalah salah satu kegiatan yang dilakukan guru sebelum ia melaksanakan pembelajaran di kelas. Muslich (2008) mengemukakan, bahwa rencana pelaksanaan pembelajaran adalah rancangan pembelajaran mata pelajaran per unit yang akan diterapkan guru dalam
Kemendikbud (2013) juga mengungkapkan bahwa setiap guru pada satuan pendidikan berkewajiban menyusun RPP secara lengkap dan sistematis agar pembelajaran berlangsung dengan baik. RPP yang disusun secara lengkap dan sistematis akan membuat pembelajaran berlangsung secara interaktif, inspiratif, menyenangkan, menantang, memotivasi peserta didik untuk berpartisipasi aktif, serta memberikan ruang yang cukup bagi prakarsa, kreativitas, dan kemandirian sesuai dengan bakat, minat, dan Untuk mengakomodasi hal tersebut diatas, maka dalam Kurikulum 2013, guru harus menerapkan pendekatan saintifik di dalam Rencana Pelaksanaan Pembelajarannya (Kemendikbud, 2013). Pencantuman pendekatan saintifik ini dalam RPP adalah pada komponen merencanakan kegiatan pembelajaran atau perkembangan fisik serta psikologis peserta didik. 


\section{Gorga Jurnal Seni Rupa \\ Volume 07 Nomor 02 \\ p-ISSN: 2301-5942 | e-ISSN: 2580-2380}

langkah-langkah

kegiatan inti.

pembelajaran terutama dalam

Salah satu perbedaan yang dominan antara RPP KTSP dengan RPP Kurikulum 2013 adalah pada komponen merencanakan kegiatan pembelajaran. Dalam KTSP komponen merencanakan kegiatan pembelajaran berisi kegiatan eksplorasi, elaborasi dan konfirmasi, sedangkan pada pada Kurikulum 2013 berisi pendekatan saintifik dengan kegiatan mengamati, bertanya, mengumpulkan informasi, mengasosiasi/menalar dan mengkomunikasikan.

\section{Strategi Pembelajaran}

Kualitas proses pembelajaran dapat dilihat dari pencapaian tujuan pembelajaran atau perolehan hasil belajar. Hasil belajar yang tinggi mengindikatorkan kualitas pembelajaran baik, sebaliknya hasil belajar yang rendah mengidentifikasikan kualitas pembelajaran yang rendah atau tidak baik. Upaya peningkatan kualitas pembelajaran dapat berupa pemilihan dan penetapan strategi pembelajaran yang optimal untuk mencapai hasil belajar sesuai dengan tujuan pembelajaran yang telah ditetapkan.

Dalam strategi pembelajaran, kegiatan pembelajaran tidak hanya dikerjakan oleh guru saja atau siswa saja, tetapi keduanya harus terlibat. Sebagaimana yang dikemukakan oleh Kemp dalam Sanjaya (2006) bahwa "strategi pembelajaran adalah suatu kegiatan pembelajaran yang harus dikerjakan guru dan siswa agar tujuan pembelajaran dapat dicapai secara efektif dan efesien. Pengertian yang lebih spesifik dikemukakan oleh Sujana dan Suwariyah (1991), bahwa "strategi pembelajaran adalah setiap kegiatan, baik prosedur, langkah, maupun metode dan teknik yang dipilih agar dapat memberikan kemudahan, fasilitas dan atau bahan bantuan lain kepada mahasiswa dalam mencapai tujuan pembelajaran", Berdasarkan penjelasan tersebut dapat disimpulkan, bahwa strategi pembelajaran adalah merupakan suatu rangkaian kegiatan yang dipilih guru dalam proses pembelajaran yang dapat memberikan kemudahan atau fasilitas pada mahasiswa agar tujuan pembelajaran dapat dicapai secara efektif dan efesien. Oleh sebab itu strategi pembelajaran merupakan hal yang perlu diperhatikan dalam proses.

Strategi pembelajaran pada kurikulum 2013 memiliki karakteristik yang berbeda dari proses pembelajaran pada kurikulum 2006. Proses pembelajaran dalam konteks kurikulum 2013 pada satuan pendidikan harus diselenggarakan secara interaktif, inspiratif, menyenangkan, menantang, memotivasi peserta didik untuk berpartisipasi aktif, serta memberikan ruang yang cukup bagi prakarsa, kreatif, dan kemandirian sesuai dengan bakat, minat dan perkembangan fisik serta psikologis peserta didik (Kemendikbud, 2013). Maka dari itu pendekatan yang dapat mendorong siswa ke arah itu adalah pendekatan saintifik. Hal ini telah diisyaratkan pemerintah dalam Permendikbud Nomor 65 Tahun 2013 tentang Standar Proses Pendidikan Dasar dan Menengah, tentang perlunya proses pembelajaran yang dipandu dengan kaidahkaidah pendekatan ilmiah/saintifik, termasuk melaksanakan strategi pembelajaran.

Strategi pembelajaran yang menggunakan pendekatan saintifik, ditandai dengan adanya kegiatan siswa mengamati, mempertanyakan apa yang telah diamati, mengumpulkan informasi, mengasosiasi dan mengkomunukasikan. Prinsip yang perlu diterapkan guru dalam melaksanakan strategi pembelajaran dengan menggunakan pendekatan saintifik, bahwa dalam proses pembelajaran penekanannya bukan pada apa yang harus dipelajari siswa, melainkan bagaimana siswa tersebut harus mempelajarinya. Untuk itu kondisi pembelajaran diarahkan untuk mendorong siswa dalam mencari tahu dari berbagai sumber informasi, bukan diberi tahu, (Majid dan Rochman, 2014).

\section{METODE PENELITIAN}

Jenis penelitian yang digunakan dalam penelitian ini adalah deskriptif kualitatif. Jenis penelitian ini digunakan untuk mendeskripsikan pelaksanaan pembelajaran berbasis pendekatan saintifik pada mata pelajaran seni budaya materi seni rupa di SMPN Bukittinggi. Penelitian ini tidak memberikan perlakuan, manipulasi, atau pengubahan pada variabel-variabel bebas, tetapi menggambarkan suatu kondisi apaadanya.

Subjek penelitian merupakan seseorang yang darinya diperoleh keterangan. Keterangan yang dibutuhkan peneliti yaitu tentang pelaksanaan pembelajaran berbasis pendekatan saintifik di SMPN 6 dan SMPN 8 Bukittinggi, sehingga subjek atau informan dalam penelitian ini adalah guru seni budaya dan siswa.

Data yang diperlukan dalam untuk mengetahui pelaksanaan pembelajaran seni rupa berbasis pendekatan saintifik di SMP Negeri 6 dan SMP Negeri 8 Bukittinggi diperoleh dengan menggunakan teknik observasi, wawancara dan dokumentasi. Sedangkan alat pengumpul datanya adalah lembaran observasi dan pedoman wawancara 


\section{Gorga Jurnal Seni Rupa \\ Volume 07 Nomor 02 \\ p-ISSN: 2301-5942 | e-ISSN: 2580-2380}

Penelitian ini menggunakan teknik analisis data dilapangan model Miles dan Huberman. Miles dan Huberman (1992:20) mengemukakan bahwa aktifitas dalam analisis data kualitatif dilakukan secara interaktif dan berlangsung secara terus menerus sampai tuntas, sehingga datanya jenuh. Aktifitas dalam analisisdata ini adalah: 1) reduksi, yang berarti merangkum, memilih hal-hal pokok dan penting kemudian dicari tema dan polanya, 2) penyajian data, data disajikan dalam bentuk tabel dan uraian penjelasan yang bersifat deskriptif dan 3) penarikan kesimpulan, berarti setelah semua data tersaji permasalahan yang menjadi objek penelitian dapat dipahami dan kemudian ditarik kesimpulan yang merupakan hasil dari penelitian ini.

Teknik yang digunakan untuk menguji objektivitas dan keabsahan data pada penelitian ini adalah triangulasi. Teknik triangulasi yang digunakan dalam penelitian ini adalah triangulasi dengan memanfaatkan berbagai sumber, berarti membandingkan dan mengecek balik derajat kepercayaan suatu informasi yang diperoleh dengan jalan: 1) membandingkan data hasil pengamatan dengan data hasil wawancara, 2) Membandingkan hasil wawancara dengan isi suatu dokumen yangterkait.

\section{HASIL DAN PEMBAHASAN}

\section{Rencana Pelaksanaan Pembelajaran (RPP) Pembelajaran Seni Rupa}

Berdasarkan hasil observasi di SMPN 6 Bukittinggi masih ada komponen-komponen penyusunan RPP yang belum berdasarkan Kurikulum 2013, seperti tidak menuliskan model dan pendekatan yang digunakan berdasarkan kurikulum 2013. Langkahlangkah pembelajaran terutama pada kegiatan inti masih ada penyusunannya berdasarkan KTSP dan tidak terlihat langkah-langkah pembelajaran berdasarkan pendekatan saintifik. Selain itu, penilaian yang ditulis pada RPP masih ada yang belum menggunakan penilaian autentik yang terdiri dari tiga ranah yaitu penilaian sikap, pengetahuan, dan keterampilan peserta didik. Namun demikian sudah banyak guru-guru seni budaya yang menggunakan pendekatan saintifik dalam RPP terutama dalam langkah-langkah pembelajaran.

Di SMPN 8 Bukittinggi hampir sama dengan SMPN 6 Bukittinggi, penyusunan RPP yang dilakukan oleh guru Seni Budaya masih ada yang belum berdasarkan Kurikulum 2013, seperti langkah-langkah pembelajaran dan penilaian. Dalam perumusan langkah-langkah pembelajaran terutama pada kegiatan inti, masih ada guru yang merumuskan berdasarkan
KTSP yakni eksplorasi, elaborasi dan konfirmasi. Padahal dalam kurikulum 2013, perumusan kegiatan inti harus menggunakan pendekatan saintifik, yakni mengamati, menanya, mengumpulkan informasi, mengasosiasi dan mengkomunikasikan(Wisdiarman, 2017).

Berdasarkan observasi terhadap RPP pembelajaran seni budaya di kedua SMPN terlihat bahwa guru-guru pada umumnya sudah merumuskannya menggunakan pendekatan saintifik. Namun masih ada uraian masing-masing langkah pendekatan saintifik yang tidak sesuai, seperti pada langkah mengamati dan mengkomunikasikan. Pada langkah mengamati dirumuskan kegiatan siswa, antara lain; membaca sumber-sumber tertulis, mendengarkan informasi lisan, melihat gambar, menonton tayangan dan menyaksikan fenomena alam. Sedangkan langkah mengkomunikasikan yang dirumuskan adalah, antara lain; membacakan atau mempresentasikan hasil diskusi untuk mendapatkan tanggapan dari siswa lain dan memajang karya di dinding (Kosasih, 2016). Sementara langkah mengamati yang dirumuskan guru dalam RPPadalah menerangkan materi pembelajaran. Begitu juga dengan langkah mengkomunikasikan, yang dirumuskan guru adalah kegiatan menyimpulkan. Disamping itu rumusan pendekatan saintifik pada kegiatan inti masih ada yang merumuskan kegiatan guru, pada seharusnya yang dirumuskan tersebut adalah kegiatan siswa.

Begitu juga dengan hasil wawancara dengan guru Seni Budaya SMP Negeri 6 Bukittinggi. Dijelaskan bahwa RPP telah dibuat sesuai dengan format RPP pada kurikulum 2013. Khusus pada langkah-langkah pembelajaran guru telah merumuskan seperti yang diamanatkan kurikulum 2013 yakni menggunakan pendekatan saintifik. Langkah-langkah pembelajarannya sudah menggunakan kegiatan $5 \mathrm{M}$, yakni mengamati, menanya, mengumpulkan informasi, mengasosiasi dan mengkomunikasikan.

Sehubungan dengan perumusan masing-masing langkah dalam pendekatan saintifik, guru masih bingung dalam merumuskannya. Misalnya pada kegiatan mengamati, guru merumuskan kegiatan guru bukan kegiatan siswa. Yang dirumuskan guru pada kegiatan mengamati tersebut adalah "guru menjelaskan materi pembelajaran dengan menggunakan media pembelajaran". Kemudian dalam kegiatan menanya, guru melakukan tanya jawab bukan siswa mempertanyakan tentang apa yang telah diamatinya tadi. Begitu juga kegiatan mengumpulkan informasi, guru merumuskan tentang membaca 


\section{Gorga Jurnal Seni Rupa \\ Volume 07 Nomor 02 \\ p-ISSN: 2301-5942 | e-ISSN: 2580-2380}

kembali buku paket yang sudah dibaca pada kegiatan mengamati. Dalam mengasosiasi guru tidak mengajak siswa untuk membahas dengan diskusi, tapi langsung disuruh membauat tugas. Terakhir mengkomunikasikan, guru hanya meminta siswa memperlihatkan tugasnya pada guru. Setelah ditanya apakah gur-guru memahami tentang pendekatan saintifik, guru menjawab tidak begitu paham dalam merumuskan masing-masing kegaiatan pendekatan saintifik tersebut.

Begitu juga dengan wawancara dengan guru seni budaya SMP Negeri 8 Bukittinggi. Dijelaskan bahwa guru juga telah menggunakan pendekatan saintifik pada RPP pembelajaran seni budaya, yakni mengamati, menanya, mengumpulkan informasi, mengasosiasi dan mengkomunikasikan. Namun dia merasa bingung dengan rumusan masing-masing kegiatan pendekatan saintifik, sehingga dia merumuskan asal-asalan saja. Seperti dalam mengamati, yang dirumuskan adalah kegiatan guru menerangkan pelajaran. Pada kegiatan menanya, yang dirumuskan adalah siswa bertanya pada guru tentang materi. Pada kegiatan mengumpulkan informasi, yang dirumuskan adalah mencari buku-buku yang penunjang dan pada kegiatan mengkomunikasikan, yang dirumskan adalah guru memberi tahu tentang hasil yang dicapai siswa.

\section{Strategi Pembelajaran Seni Rupa}

Berdasarkan hasil observasi yang dilakukan di SMP Negeri 6 dan SMP Negeri 8 Bukittinggi guru tidak terlihat menggunakan strategi/model pembelajaran berdasarkan Kurikulum 2013. Guru banyak menggunakan metode ceramah, tanya jawab dan langsung memberikan tugas. Guru lebih banyak menjelaskan materi pembelajaran, sedangkan siswa mendengar dan mencatat. tanpa adanya keaktifan peserta didik dalam proses pembelajaran. Sementara ada guru yang sudah menerapkan pendekatan santifik dalam proses pembelajaran, namun belum maksimal. Seperti dalam langkah mengumpulkan informasi siswa mencari sumber lain, yang ada hanya guru menyuruh siswa membaca buku paket yang sudah dipakainya pada langkah mengamati. Disamping itu juga pelaksanaan pendekatan saintifik tidak dilengkapi dengan peralatan yang cukup.

Sama halnya obervasi yng dilakukan di SMPN 8 Bukittinggi. Guru seni budaya belum menggunakan strategi/model yang diamanatkan oleh kurikulum 2013. Guru banyak menggunakan metode ceramah, sekali-sekalim diselingi dengan tanya jawab, kemudian memberikan tugas. Guru lebih banyak menyuruh siswa membuat tugas. dan langsung memberikan tugas.

Begitu juga hasil wawancara dengan guru Seni Budaya SMP Negeri 6 Bukittinggi. Dijelaskan bahwa dalam pelaksanaan pembelajaran guru belum maksimal menggunakan model pembelajaran seperti yang dituntut dalam kurikulum 2013, yakni model discovery learning, inquiy learning, project based learning dan problem based learning. Guru masih menggunakan model lama yakni menjelaskan materi pada siswa yang diselingi dengan tanya jawab, kemudian siswa diberi tugas. Guru jarang disuruh untuk menemukan sendiri materi yang akan dipelajarinya. Guru jarang mengajak siswa mendiskusikan materi. Guru juga tidak pernah menyuruh siswa untuk mempertanyakan materi, yang ada hanya guru bertanya pada siswa.

Hal yang sama juga dialami oleh guru seni budaya SMP Negeri 8 Bukittinggi, yakniguru-guru belum menggunakan pendekatan saintifik dalam proses pembelajaran. Karena menurut dia pendekatan saintifik membutuhkan waktu yang panjang dan ketersediaan fasilitas yang memadai. Maka dari itu, guru lebih senang mengajar dengan cara lama, yakni menyajikan materi pada siswa. Selain itu guru juga belum paham dengan pendekatan saintifik.

Berdasarkan observasi, wawancara dan dokumen yang didapat, ternyata masih banyak guru-guru yang belum melaksanakan pembelajaran menggunakan pendekatan saintifik secara baik. Baik renacana Pelaksanaan pembelajaran (RPP), maupun strategi/model pembelajarannya. Padahal SMPN Bukittinggi telah menerapkan kurikukulum 2013. Pembelajaran dengan pendekatan saintifik, siswa siswa berperan secara langsung, baik secara individu mauun secara kelompok untuk menggali konsep dan prinsip selama kegiatan pembelajaran, sedangkan tugas guru adalah mengarahkan proses belajar yang dilakukan siswa dan memberikan koreksi terhadap konsep dan prinsip yang didapatkan siswa (Sami, 2017). Konsep dalam pendekatan saintifik adalah, bahwa dalam proses pembelajaran penekanannya bukan pada apa yang harus dipelajari siswa, melainkan bagaimana siswa tersebut harus mempelajarinya. Untuk itu kondisi pembelajaran diarahkan untuk mendorong siswa dalam mencari tahu dari berbagai sumber informasi, bukan diberi tahu (Majid dan Rochman, 2014).

Dengan diterapkannya pendekatan saintifik akan dapat mendorong dan menginspirasi siswa menjadi kritis, 


\section{Gorga Jurnal Seni Rupa \\ Volume 07 Nomor 02 \\ p-ISSN: 2301-5942 | e-ISSN: 2580-2380}

analitis, tepat dalam mengidentifikasi, memahami, menerapkan dan mengembangkan pola fikir yang rasional dan objektif dalam merespon substansi atau materi pembelajaran. Oleh sebab itu dalam pelaksanaan pembelajaran, guru-guru harus menggunakan pendekatan saintifik ini, baik dalam pembuatan RPP maupun dalam strategi/ model pembelajaran.

\section{KESIMPULAN DAN SARAN}

\section{Kesimpulan}

Berdasarkan hasil penelitian mengenai pelaksanaan pembelajaran berbasis pendekatan saintifik pada mata pelajaran seni budaya materi seni rupa di SMPN Bukittinggi, dapat ditarik kesimpulan sebagai berikut:

1. Guru seni budaya SMPN 6 dan SMPN 8 Bukittinggi sudah membuat Rencana Pelaksanaan Pembelajaran (RPP) berdasarkan pendekatan saintifik. Tetapi dalam perumusan masing-masing langkah belum sesuai dengan ketentuannya.

2. Guru seni budaya SMPN 6 dan SMPN 8 Bukittinggi belum lagi melaksanakan strategi pembelajaran berdasarkan pendekatan saintifik sesuai dengan yang diharapkan. Hal ini karena ketidak pahaman guru terhadap penggunaan model dan langkah-langkah kegiatan pembelajaran berdasarkan pendekatan saintifik.

\section{Saran}

Berdasarkan kesimpulan yang telah dikemukakan, maka dalam kesempatan ini penulis menyampaikan beberapa saran sebagai berkut:

1. Bagi guru, diharapkan guru aktif mengikuti kegiatan yang dilakukan pemerintah maupun sekolah seperti penataran, workshop yang terkait dengan pelaksanaan kurikulum 2013, terutama pendekatan saintifik. Hal ini dikarenakan agar semua guru mengerti dan memahami secara mendalam tentang implementasi Kurikulum 2013 terutama dalam menerapkan pendekatan saintifik dalam pembelajaran.

2. Bagi sekolah, diharapkan sekolah memberikan sosialisasi guru terutama guru Seni Budaya dalam pembelajaran Seni Rupa agar guru lebih memahami bagaimana penerapan pendekatan saintifik.

3. Bagi peneliti, semoga dapat bermanfaat untuk menambah wawasan dan pengalaman dalam penerapan pendekatan saintifik khususnya pada pembelajaran Seni Rupa.

\section{DAFTAR RUJUKAN}

Hamalik, Oemar.(2001). Perencanaan Pengajaran

Berdasarkan Pendekatan Sistem. Jakarta:

Bumi Aksara.

Kementerian Pendidikan dan Kebudayaan. (2013).

Peraturan Menteri Pendidikan dan

Kebudayaan Republik Indonesia Nomor 65

Tahun 2013 Tentang Standar Proses

Pendidikan Dasar dan Menengah (2013).

Jakarta: Kementerian Pendidikan dan

Kebudayaan

...(2013). Penyusunan Rencana

Pelaksanaan Pembelajaran (RPP) Mengacu

pada Standar Proses Dengan Menggunakan

Pendekatan Saintifik dan Penilaian Autentik.

Jakarta: Kementerian Pendidikan dan

Kebudayaan.

Kosasih. (2016). Strategi Belajar dan Pembelajaran. Implementasi Kurikulum 2013. Bandung:

Yrama Widya

Kurniasih, Imas dan Sani, Berlin. ( 2014). Sukses mengimplementasikan Kurikulum 2013.

Jakarta: Kata Pena.

.(2016). Revisi Kurikulum 2013.

Implementasi Konsep dan Penerapannya.

Jakarta: Kata Pena

Majid, Abdul. (2005). Perencanaan Pembelajaran.

Bandung: Remaja Rosdakarya.

Majid dan Rochman. (2014). Pendekatan Ilmiah.

Dalam Implementasi Kurikulum 2013.

Bandung: Remaja Rosdakarya.

Sami, Yasrul. (2017). Implementasi Pendekatan

Saintifik Ditinjau Dari Motivasi belakjar

Mahasiswa Pada mata Kuliah Nirmana (Dwi

Matra). Jurnal Ranah Seni. Volume 11,

No.01, september 2017, hal. 235-244

Sanjaya, Wina (2006). Strategi Pembelajaran. Jakarta:

Sudjana, Nana dan Suwariyah, Wari. 1991. Model-

Model Mengajar CBSA. Bandung: Sinar Baru

Wisdiarman dan Zubaidah. (2014). Pembelajaran

Berbasis Kurikulum 2013. Padang: Seni

Rupa FBS UNP Padang (2017). Analisis Kebutuhan

LK S Berbasis Pendekatan Saintifik Dengan Model Discovery LearningPada Mata Pelajaran Seni Budaya Materi Seni Rupa di SMP. Jurnal Komposisi.Volume XVIII.No.1 2017. Hal.80-89 Kencana Prenada Media. 